\title{
Effects of environmental pollution with aromatic hydrocarbons on endocrine and metabolic functions of the human placenta
}

\author{
Waldemar Wierzba', Stanisław Radowicki², Iwona Bojar ${ }^{3}$, Jarosław Pinkas ${ }^{4}$ \\ ${ }^{1}$ University of Humanities and Economics in Łódź, UHE Satellite Campus in Warsaw, Warsaw, Poland \\ ${ }^{2}$ Department of Gynecological Endocrinology, Medical University of Warsaw, Poland \\ ${ }^{3}$ Institute of Rural Health in Lublin, Poland \\ ${ }^{4}$ Center of Postgraduate Medical Education, Warsaw, Poland.
}

Wierzba W, Radowicki S, Bojar I, Pinkas J. Effects of environmental pollution with aromatic hydrocarbons on endocrine and metabolic functions of the human placenta. Ann Agric Environ Med. 2018; 25(1): 157-161. doi: 10.26444/aaem/74406

\begin{abstract}
Introduction. Phenol and 1-hydroxypyrene are biological markers of exposure to polycyclic aromatic hydrocarbons (PAH) that have certain negative effects on parenchymal organs such as the human placenta. The literature presents only few reports regarding the effects of elevated PAH levels on the functions of the human placenta.

Objective. The aim of the work is to assess the effects of elevated PAH levels in excreted urine on the endocrine and metabolic functions of the human placenta obtained from a normal pregnancy.

Material and methods. Tissue material from 50 afterbirths from Płock constituted a study group, whereas 50 afterbirths from Kutno constituted a control group. Immunohistochemical reactions with the peroxidase method using LSAB kits (DAKO, Denmark) were performed. The extent and intensity of reactions were analysed. The levels of phenols and 1-hydroxypyrene in the excreted urine of pregnant women (undergoing delivery) were detected using gas chromatography and colorimetry. The statistical analysis used the PQStat v.1.6.2 software; moreover, t-student and chi-square tests were used. Differences were considered to be significant at the significance level of $95 \%(p<0.05)$.

Results. The levels of phenol and 1-hydroxypyrene in the excreted urine were demonstrated to be statistically significantly higher in patients living in the area of Płock. Statistically lower expression of placental glutathione transferase and lower immunohistochemical demonstration of the placental phosphatase activity were observed in placentas from Płock. It has been demonstrated that the expression of the oestrogen receptor activity and placental gonadotropin is significantly higher in placentas from areas not contaminated with aromatic hydrocarbons (Kutno).

Conclusions. The course of pregnancy in the environment with elevated levels of aromatic hydrocarbons leads to impaired placental functioning and reduced endocrine and metabolic activity of the placenta.
\end{abstract}

Key words

Human placenta, Endocrine and Metabolic functions, Aromatic hydrocarbons, Phenol, 1-hydroxypiren

\section{INTRODUCTION}

Studies presented in this publication were a part of a large research project regarding the effects of petrochemical contamination on the health status of inhabitants of Płock. Human placenta has two major roles: it is an organ responsible for transfer of metabolites and it is a place where hormones and enzymes necessary for a growing foetus are produced or metabolised. For the foetus, it functions as lungs, gastrointestinal tract, kidneys and the whole system of endocrine glands, including liver $[1,2]$.

Placenta's own metabolism is extremely active. Its individual components, especially their functional performance, indicate foetal well-being. With regard to earlier studies the trophoblastic epithelium seems to be the most active component of the afterbirth. The placental connective tissue is a component that so far has been poorly studied. Few papers indicate it regulates placental functioning $[3,4,5]$.

Address for correspondence: Waldemar Wierzba, University of Humanities and Economics in Łódź, UHE Satellite Campus in Warsaw, Warsaw, Poland, L. Hirszfelda 11 Street, 02-776 Warsaw

E-mail: wwierzba@post.pl

Received: 18 March 2017; accepted: 9 May 2017; first published on June 2017
Aromatic hydrocarbons, especially phenol, are highly toxic to numerous cellular structures such as parenchymal organs (liver, lungs, placenta) and haematopoietic system $[6,7,8]$. Liebhart and Pawinski observed damage to the trophoblastic epithelium, its increased remodelling and renewal in human placentas from the area of Płock due to exposure to petrochemical industry in women with high urine excretion of phenol [9].

The placental barrier separating the maternal circulation from the foetal circulation reduces availability of chemical substances to the foetus to a relatively low extent.

As the levels of aromatic hydrocarbons in the air in the area around refineries and petrochemical plants are significantly higher it results in dangerous chronic intoxication that has an asymptomatic course and therefore only after certain period of time it is possible to observe numerous injuries to organs and tissues $[10,11]$.

Significantly elevated (significantly higher) levels of phenols and 1-hydroxypyrene in the excreted urine are biological markers of exposure (intoxication) to polycyclic aromatic hydrocarbons $[12,13,14]$.

The effects of contamination with aromatic hydrocarbons on parenchymal organs may be assessed by studying and comparing afterbirths from normal pregnancies in the 
environment with increased phenol levels and afterbirths from the areas without contamination with such substances $[15,16,17]$.

\section{OBJECTIVES OF THE STUDY}

The aim of the work is to assess the effects of elevated levels of aromatic hydrocarbons in the excreted urine on the endocrine and metabolic functions of the human placental tissue based on the evaluation of the extent and intensity of immunohistochemical colour-producing reactions with specific antibodies [18].

\section{MATERIALS AND METHODS}

The study material was collected from patients with a negative medical history whose pregnancies were in the environment exposed to elevated levels of aromatic hydrocarbons (AH) in the air (study group - Płock) and patients from the environment without AH contamination (control group Kutno). A precondition for enrolling afterbirth into the study was uncomplicated physiological full-term pregnancy (39-41 week). All observed pregnancies resulted in a spontaneous labour and healthy children were born (Apgar score of 10). Prior to pregnancy patients had not been suffering from any chronic diseases, were not smokers and did not abuse alcohol or drugs. Patients in the control and study group did not differ significantly with regard to the age, parity and body weight. Children born as a result of these pregnancies did not differ statistically with regard to their birth weight. During pregnancy and delivery each patient had urine phenol levels assessed three times in order to obtain information on the total exposure to hydrocarbons as their urine metabolites are simple phenols. Phenol levels were assessed using three methods: HPLC (liquid chromatography), GC (gas chromatography) and a colorimetric method with 4-aminoantipyrine. Additionally, the urine levels of 1-hydroxypyrene were determined with gas chromatography as it is a biological marker of exposure to polycyclic aromatic hydrocarbons $[13,19]$.

Tissue material from 50 afterbirths from Płock constituted a study group, whereas 50 afterbirths from Kutno constituted a control group. In all cases two specimens were collected from the umbilical cord, one from the extraplacental foetal membranes and two or three specimens from the placenta itself. All 550 specimens obtained were processed in order to obtain paraffin-embedded blocks. Paraffin-embedded blocks were used to obtain slides for routine histopathological evaluation and then the most representative placental slides were selected for further immunohistochemical tests. Histopathological evaluation was performed after routine staining with hematoxylin and eosin. Preliminary results did not show significant histopathological differences in both groups of placentas, namely the study group from Płock and the control group from Kutno.

Then, immunohistochemical reactions in selected slides from 50 evaluated placentas (without specimens from the umbilical cord or foetal membranes) from the area with environmental contamination (Płock) and also in slides from 50 placentas from the control group (Kutno area) were performed. Results obtained - intensity and extent of immunohistochemical reactions - were used as a basis to conduct a comparatory analysis of expression of various reaction products indicating metabolic and endocrine functions. Immunohistochemical reactions were performed in order to detect differences with regard to maturity, metabolic performance and endocrine functioning in placentas in both assessed groups.

Immunohistochemical reactions were performed with the peroxidase method using LSAB kits (HRP Rabbit/Mouse Universal LSAB 2 Kits by DAKO, Denmark). They are based on the sequential use of biotinylated antibody cross-linkers conjugated with streptavidin, with horseradish peroxidase. This method is extremely sensitive and low levels of primary antibodies can be detected.

Immunohistochemical reactions with the following antibodies were performed:

\section{A. Indicating the endocrine activity of the placenta:}

A1. Rb a Hu Chorionic Gonadotropin (hCG), glycoprotein, placental gonadotropin, placental beta fraction, synthesised in placental syncytiotrophoblast cells;

$\mathrm{A} 2$. $\mathrm{Rb}$ a $\mathrm{Hu}$ Placental lactogen (hPL), polypeptide hormone, somatommamotrophin, regarding its functions it is analogous to the growth hormone, its synthesis takes place in placental trophoblast cells;

A3. Mo o A Hu Estrogen Receptor, indicating the activity of trophoblastic cells involved in the production of the hormone, its expression indicates good performance of the foetal-placental unit;

\section{B. Indicating the metabolic activity of the placenta:}

B1. Mo a Hu Glutathione-S-Transferase Pi, known as Placental Glutathione-S-Transferase $\mathrm{Pi}$, indicating $\mathrm{Pi}$ microsomal fraction of the placental cells, mainly epithelial cells;

B2. Mo a Hu Placental Alkaline Phosphatase, immunohistochemical demonstration of the activity of specific placental phosphatase, the best known enzyme involved in metabolic processes and active growth of the placental tissue.

Reactions were assessed with two methods. Firstly, they were assessed using an arbitrary 4-point scale: $0,1,2,3$, where $0=$ no reaction, $3=$ strong, even reaction.

Additionally, immunohistochemical reactions performed were assessed with regard to their extent and intensity using the computer system for morphometric assessment, namely Cell Soft Imaging System by Olympus; and it was possible by combining a light microscope with a digital camera (Olympus BX41, Olympus C3040) with a computer. Results of immunohistochemical tests were made more objective thanks to such an assessment. Differences were considered to be statistically significant at the significance level of $95 \%$ $(\mathrm{p}<0.05)$.

Results obtained were subject to a statistical analysis with the PQStat v.1.6.1 Software. T-student and chi-square tests of independence were used.

\section{RESULTS}

The levels of phenol and 1-hydroxypyrene in the excreted urine were statistically significantly higher in patients living in the area of Płock (table 1). 
Table 1. The urine levels of excreted phenol and 1-hydroxypyrene in pregnant women

\begin{tabular}{|c|c|c|c|c|}
\hline Study groups & $\begin{array}{c}\text { Phenol met. } \\
\text { Hplc [mg/l] } \\
(X+/-S D)\end{array}$ & $\begin{array}{l}\text { Phenol met. Gc } \\
{[\mathrm{mg} / \mathrm{l}](\mathrm{X}+/-\mathrm{SD})}\end{array}$ & $\begin{array}{l}\text { Phenol met. } \\
\text { with 4-amino- } \\
\text { antipyrine } \\
\text { [mg/l] }(\mathrm{X}+/-\mathrm{SD})\end{array}$ & $\begin{array}{c}\text { 1-hydroxy- } \\
\text { pyrene [mg/l] } \\
(\mathrm{X}+/-\mathrm{SD})\end{array}$ \\
\hline $\begin{array}{l}\text { KUTNO } \\
\mathrm{n}=50\end{array}$ & $\begin{array}{c}2.025+/- \\
0.767\end{array}$ & $2.044+/-0,754$ & $5.059+/-0,788$ & $\begin{array}{c}0.225+/- \\
0.169\end{array}$ \\
\hline $\begin{array}{l}P Ł O C K \\
n=50\end{array}$ & $\begin{array}{c}4.419+/- \\
2,484\end{array}$ & $4.455+/-2.624$ & $8.735+/-2,835$ & $\begin{array}{c}0.519+/- \\
0.366\end{array}$ \\
\hline $\begin{array}{l}\text { T-student test } \\
\text { for independent } \\
\text { samples }\end{array}$ & $\begin{array}{c}t=6.5115 ; \\
k=98 \\
p<0.001\end{array}$ & $\begin{array}{c}t=6.2443 ; k=98 \\
p<0.001\end{array}$ & $\begin{array}{c}t=8.8337 ; k=98 \\
p<0.001\end{array}$ & $\begin{array}{c}\mathrm{t}=5.156831 ; \\
\mathrm{k}=98 \\
\mathrm{p}<0.001\end{array}$ \\
\hline
\end{tabular}

Dimensions of placentas from the Płock group were greater, on average, compared to the Kutno group, but this difference was not statistically significant $(\mathrm{p}=0.064)$.

The analysis of the endocrine functioning of the placenta based on the extent and intensity of reactions showed differences between studied populations.

The assay for placental gonadotropin ( $\mathrm{Rb}$ a $\mathrm{Hu}$ Chorionic Gonadotropin HCG antibodies) that is synthesised by the syncytiotrophoblast cells showed statistically significantly higher activity of placentas in the Kutno group compared to the Płock group $(\mathrm{p}<0.01)$ (tables 2,3).

Table 2. The intensity of reaction of placental gonadotropin in syncytiotrophoblast cells

\begin{tabular}{lcccc}
\hline \multirow{2}{*}{ Groups } & \multicolumn{4}{c}{ The intensity of the reaction } \\
\cline { 2 - 5 } & No reaction & $\begin{array}{c}\text { Trace } \\
\text { reaction }\end{array}$ & $\begin{array}{c}\text { Poor } \\
\text { reaction }\end{array}$ & $\begin{array}{c}\text { Strong } \\
\text { reaction }\end{array}$ \\
\hline Study group $(\mathrm{n}=50)$ & $0(0 \%)$ & $10(20 \%)$ & $15(30 \%)$ & $25(50 \%)$ \\
\hline Control group $(\mathrm{n}=50)$ & $3(15 \%)$ & $21(42 \%)$ & $16(32 \%)$ & $10(20 \%)$ \\
\hline $\begin{array}{l}\text { Chi-square test } \\
\text { of independence }\end{array}$ & Chi-square statistics=13.364; Degrees of freedom=3; \\
\hline
\end{tabular}

Table 3. The extent of moderate and high colour-producing reactions of placental gonadotropin in syncytiotrophoblast cells

\begin{tabular}{lccc}
\hline \multirow{2}{*}{ Groups } & Number & \multicolumn{2}{c}{ Average area (X+/-SD) } \\
\cline { 3 - 4 } & $(\mathrm{n})$ & {$\left[\mu \mathrm{m}^{2}\right]$} & {$[\%]$} \\
\hline Study group (Płock) & 50 & $28913.15+/-21548.27$ & $20.10+/-14.98$ \\
\hline Control group (Kutno) & 50 & $20171.51+/-13502.21$ & $14.02+/-9.39$ \\
\hline $\begin{array}{l}\text { T-student test for independent } \\
\text { samples }\end{array}$ & $\mathrm{t}=2,430789 ; \mathrm{k}=98$ & $\mathrm{t}=2,431021 ; \mathrm{k}=98$ \\
$\mathrm{p}=0,016884$ & $\mathrm{p}=0,016874$ \\
\hline
\end{tabular}

For all reactions described below, calculation was performed as in Tables 2 and 3. These tables are not located in the text, due to the transparency of the publication. Describes only the results.

The expression of oestrogen receptors (detected by Mo o A Hu Estrogen Receptor ER antibodies) that indicate the activity of trophoblast cells involved in the production of this hormone showed significantly higher activity in the placentas from the Kutno group $(\mathrm{p}<0.01)$.

An analogous assay for the activity of placental somatomammotrophin (hCS) (Rb a Hu Placental Lactogen HPL antibodies), a polypeptide hormone previously known as placental lactogen (hPL), synthesised by trophoblast cells showed higher average values in the Płock population; however, they were not statistically significant ( $\mathrm{p}>0.05)$.

Significantly higher expression of the oestrogen receptor activity and placental gonadotropin indicates that the foetalplacental unit shows better performance in placentas from the area not contaminated with aromatic hydrocarbons (Kutno).

The analysis of the metabolic activity of placentas indicated by the expression of placental glutathione transferase (Mo a $\mathrm{Hu}$ Glutathione-S-Transferase Pi antibodies) that indicates the Pi microsomal fraction of epithelial cells in the placental tissue showed significantly lower activity in the placentas from the Płock group $(\mathrm{p}<0.01)$.

Similarly, immunohistochemical demonstration of the activity of placental phosphatase (Mo a Hu Placental Alkaline Phosphatase PhA antibodies), an enzyme involved in metabolic processes and active growth of the placental tissue was significantly higher in the control group $(\mathrm{p}<0.01)$.

Statistically lower expression of placental glutathione transferase and lower immunohistochemical demonstration of the placental phosphatase activity indicate reduced metabolism and impaired placental functioning in the area contaminated with aromatic hydrocarbons.

\section{DISCUSSION}

Every year, the petrochemical plant in Płock emits more than 100,000 tonnes of gas substances into the atmosphere, including sulphur and nitrogen compounds, benzopyrene, hydroxypyrene and phenol. Despite the fact that in the study period and area Polish air contamination standards were not exceeded, it was unequivocally stated that the urine levels of excreted phenol (measured with three methods) and 1-hydroxypyrene (one method) in pregnant women were statistically significantly higher compared to these levels in pregnant women from the Kutno area. 1-hydroxypyrene is a biological marker of exposure to polycyclic aromatic hydrocarbons $[13,16,19]$.

It means that the Płock area is contaminated with chemical substances from the industry mentioned above, and this contamination mainly includes hydrocarbons, and additionally, all tested pregnant women were significantly affected by these substances. Papers by other authors [20, $21,22,23]$ confirm high urine levels of phenol in pregnant women living in the areas contaminated by refinery and petrochemical plants. Papers quoted showed a correlation between high levels of excreted phenol with abnormal manifestation of the afterbirth. Analyses of macroscopic, microscopic and histochemical changes were performed by such scientists as Liebhart, Pawinski, Radowicki and Wierzba in the 1970s, 1980s and 1990s. These studies demonstrated changes in the morphology and metabolism of afterbirths such as microinfarctions and excessive fibrin deposition in the intervillous space [20, 22, 23]. Lin, Li and Mao observed lower birth weight of newborns born by mothers living near petrochemical plants in Taiwan [24].

In this paper authors decided to use modern immunohistochemical methods to determine whether there are changes (differences) at the level of expression of products of reactions of antigens indicating individual placental functions in afterbirths from normal pregnancies. 
In order to do that a patient group was selected so as the only "pathology" was elevated concentration of phenol and 1-hydroxypyrene in the excreted urine, and there were no other differences between studied groups.

The study material was collected from patients with a negative medical history whose pregnancies were in the environment exposed to elevated levels of aromatic hydrocarbons (AH) in the air (study group - Płock) and patients from the environment without $\mathrm{AH}$ contamination (control group - Kutno). A precondition for enrolling afterbirth into the study was uncomplicated physiological full-term pregnancy (39-41 week). All observed pregnancies resulted in a spontaneous labour and healthy children were born (Apgar score of 10). Prior to pregnancy patients had not been suffering from any chronic diseases, were not smokers and did not abuse alcohol or drugs. Patients in the control and study group did not differ significantly with regard to the age, parity and body weight. Children born as a result of these pregnancies did not differ statistically with regard to their birth weight.

It means that the biological quality of children born in both cities is similar.

The study demonstrated that the endocrine activity of the placenta evaluated based on the activity of placental gonadotropin, expression of oestrogen receptor and activity of placental lactogen are different in these studied populations. Significantly higher expression of the oestrogen receptor activity and placental gonadotropin indicates that the foetalplacental unit shows better performance in placentas from the area not contaminated with aromatic hydrocarbons (Kutno).

Zamorska showed increased production of steroid hormones (mainly oestron and beta-oestradiol) when the activity of hydroxysteroid dehydrogenases was reduced as a compensatory phenomenon allowing to stabilise pregnancy exposed to contamination [25], On the other hand, Radowicki observed reduced activity of 3-beta-hydroxysteroid dehydrogenase in placentas exposed to high levels of phenol in the excreted urine [26].

Lower metabolic activity of placentas in the study group assessed by the expression of placental glutathione transferase and placental phosphatase indicates reduced metabolism and impaired placental functioning in the area contaminated with aromatic hydrocarbons.

Other researchers studying placental metabolism also observed lower activity of lactate dehydrogenase in the trophoblast of terminal villi, more frequent incidence of microinfarctions, excessive fibrin deposition in the intervillous space and more frequent growth of the extraplacental membrane epithelium in the group of afterbirths exposed to aromatic hydrocarbons [21].

Moreover, Radowicki observed numerous calcium deposits on the maternal surface of placentas as evidence for impaired metabolism [27].

Wierzba, on the other hand, has shown that, the foetus is protected by activation of adaptation and compensation mechanisms that are manifested as active angiogenesis and formation of new blood vessels that provide proper nutrition and oxygen supply to the foetus and significantly greater development of mesenchymal cells compared to the control group [28].

\section{CONCLUSIONS}

1. Pregnancies in Płock are statistically significantly more exposed to aromatic hydrocarbons, especially phenol and 1-hydroxypyrene, compared to those in Kutno.

2. The endocrine activity of the placental tissue obtained after delivery from women with elevated levels of phenol and 1-hydroxypyrene in the excreted urine (Płock) is statistically significantly lower compared to patients who are not exposed to aromatic hydrocarbons (Kutno).

3. The metabolic activity of the placental tissue obtained after delivery from women with elevated levels of phenol and 1-hydroxypyrene in the excreted urine (Płock) is statistically significantly lower compared to patients who are not exposed to aromatic hydrocarbons (Kutno).

\section{REFERENCES}

1. Faber JJ. Placental Physiology, Raven Press, N.Y 1983.

2. Fox H, Sebire NJ. Pathology of the Placenta, Saunders Elsevier, 2007.

3. Perrin E. Pathology of the Placenta, Churchil Livingstone, 1984.

4. Kissane JM. Andersons Pathology, Mosby, 1985.

5. Hirasawa G, Takeyama J, Sasano H, et al. 11[beta]-Hydroxysteroid Dehydrogenase Type II and Mineralocorticoid Receptor in Human Placenta. The Journal of Clinical Endocrinology and Metabolism 2000; 85(3): 1306-1309

6. McConnell EE (ed.). Enviromental Health Criteria 150. Benzen. World Health Organization, Geneva, 1993

7. Van Esch GJ (ed.). Enviromental Health Criteria 170. Tetrabromobisphenol. World Health Organization, Geneva, 1995

8. Pawlicki L, Smoczyński S, Jaworski J. Chlorowane weglowodory we krwi położnic z rejonu Olsztyna. Problemy Lekarskie 1982; 21(2): 229-237

9. Browning E. Toxicity and metabolism of industrial solvens, Elsevier, Londyn, 1965.

10. Yang C, Cheng B, Hsu T, et al. Association between Petrochemical Air Pollution and Adverse Pregnancy Outcomes in Taiwan. Archives of Environmental Health 2002; 57(5): 461-465

11. Xu X, Cho S, Sammel M, et al. Association of petrochemical exposure with spontaneous abortion. Occupational \& Environmental Medicine 1998; 55(1): 31-36.

12. Liebhart M, Pawiński R, et al. Badania patomorfologiczne kosmówki wczesnej ciąży u kobiet z podwyższonym wydalaniem fenolu i parakrezoli w moczu. Gin Pol 1980; 51(6): 11-13.

13. Brzeźnicki S, Jakubowski M. Jedno-hydroksypiren jako biologiczny marker narażenia na wielopierścieniowe węglowodory aromatyczne. Instytut Medycyny Pracy, Łódź, 1995.

14. Lis E, Garlej T. Test fenolowy w moczu jako wykładnik narażenia na węglowodory aromatyczne, Medycyna Pracy 1978; 29(1): 32-35.

15. Schönfelder G, Wittfoht W, Hopp H, et al. Parent Bisphenol A Accumulation in the Human Maternal-Fetal-Placental Unit. Environmental Health Perspectives 2002; 110(11): A703-A707.

16. Boogaard PJ, van Sittert NJ. Exposure to polycyclic aromatic hydrocarbons in petrochemical industries by measurement of urinary 1-hydroxypyrene. Occupational and Environmental Medicine 1994; 54(4): 250-258.

17. Pelkonen O, Saarni H. Unusual patterns of benzo[a]pyrene metabolites and DNA- benzo[a]pyrene adducts produced by human placental microsomes in vitro. Chemico-Biological Interactions 1980; 30(3): 287-296

18. Lösch A, Kainz C. Immunohistochemistry in the diagnosis of the gestational trophoblastic disease: Original Article. Acta Obstetricia et Gynecologica Scandinavica 1996; 75(8): 753-756

19. Chen D, Cho S, Chen C, et al. Exposure to benzene, occupational stress, and reduced birth weight. Occupational and Environmental Medicine 2000; 57(10): 661-667

20. Liebhart M, et al. Badania mikroskopowe popłodu z ciąży donoszonej z uwzględnieniem zmian toksykologicznych stwierdzonych u matki. Gin Pol 1982; 53(4): 221-227.

21. Radowicki S (ed.). Praca Zbiorowa, Porównanie przebiegu ciąży na terenie miast - Kutna i Płocka. TNP, AM Warszawa, UW Płock, 1992. 
22. Liebhart M, Rembiszewska et al., Badania histologiczne i histochemiczne popłodu z wczesnych okresów ciąży u kobiet pracujących w środowiskowych warunkach zakładów rafineryjnych. Sprawozdanie z umowy Nr 23 z MZRiP, 1978.

23. Radowicki S, Wierzba W. Macroscopic evaluation of placenta from ecologically-challenged area (Plock), part I. Gin Pol 1997; 68(2): 64-68.

24. Lin C, Li C, Mao I. Increased Risks of Term Low-Birth-Weight Infants in a Petrochemical Industrial City with High Air Pollution Levels. Archives of Environmental Health 2004; 59(12): 663-668

25. Zamorska L. Aktywność enzymów utleniających i morfologia łożysk ludzkich z ciąż donoszonych. Folia Medica Cracoviensia 1982/1983; 24(1PL): 22-25.
26. Radowicki S, Wierzba W. Dehydrogenase 3-beta-hydroxysteroid activity in placentas from physiologically pregnant women from an ecologically threatened area (Płock). Gin Pol 1997; 68(3): 123-126.

27. Radowicki S, Wierzba W. The duration of pregnancy in ecologicallychallenged area (Plock). Gin Pol 1997; 68(2): 53-58.

28. Wierzba W, Radowicki S, Bojar I, Pinkas J. The duration of pregnancy in ecologically-challenged area. The effects of environmental pollution with aromatic hydrocarbons on the angiogenesis and elements of the mesenchymal tissue of the human placenta. Gin Pol 2017; 88(4): 161-165. 